\title{
対植に対する韓国人と日本人の眼球運動の特性に 関する研究
}

\section{Studies on the Characteristics of Eye Movement to Pair Planting between Japanese and Korean Subjects}

朴 映建 ${ }^{*}$ 須田 歩** 藤井英二郎 ${ }^{* * *}$

Younggun PARK Ayumu SUDA Eijiro FUJII

\begin{abstract}
The favorite degree of several pair planting patterns and the characteristics of eye movement are analyzed to investigate the visio-psychological background of planting scheme in Korea and Japan. Korean subjects liked the pair planting pattern of the same tree form best, and their eye fixation distributed on relatively restricted area in each object tree. So, we considered the convergence of eye fixation in each tree of pair planting indicate the favorite degree of pair planting pattern in case of Korean subjects. 0n the other hand, Japanese subjects also liked the pattern of the same tree form best, and not a few subjects liked a pattern of different tree form like a cone and a globular form. And, the characteristic point of eye movement of Japanese subjects is the distribution of eye fixation between two trees. And, we could say that Japanese subjects tend to inspect the pair planting with its background and the space between the two tree. Therefore, we could point out a relationships among the favorite degree of pair planting pattern, eye movement, and general planting pattern in Korea and Japan.
\end{abstract}

Keywords: pair planting, favorite degree, eye movement, Korean, Japanese キーワード : 対植, 好みの度合い, 眼球運動, 韓国人, 日本人

\section{1. 研究の背景と目的}

日本と韓国の植栽形態はともに自然風景式とされるが，韓国農 家住宅の実態調查に基づく検討（藤井ら，1990（王) や朝鮮時代王 宮庭園の検討 (白ら，1992） ${ }^{2}$ などで指摘されているように，明 らかに異なる特徴がいくつか見られる。韓国では，植栽樹木に人 為樹形は少なく自然樹形を保つ傾向があるが, 配植では左右ほぼ 同位置にほぼ同じ大きさで同じ種類の樹木を対にして植える対植 や列植のように人為的な形式が多く見られる。これに対して，日 本では自然的ではあるが自然樹形ではなく，透かしをはじめとす る細かな剪定を加えることが多い。そして, 配植では対植や列植 などの人為的形式は避けられる傾向がある ${ }^{3)}$ 。

こうした違いは各々の国の人々の伝統的判断・嗜好の表れとも 言え,この違いは植栽形態に対する印象や生理的反応にも表れる ものと推測される。金・藤井 $\left(1992^{4)}, 1993^{5}\right)$ は, 韓国人之日本 人では幾何学的図形や自然樹形・人為樹形に対する眼球運動に異 なる傾向が見られるとした。つまり, 縦線や横線などの単純な図 形を視覚対象とした場合, 韓国人では対象に関わらず一定した見 方がみられるのに対し, 日本人では対象に則して異なる眼球運動 がみられるとしている。また, 自然樹形と人為樹形に対する印象 や眼球運動が韓国人と日本人とで異なるとした。具体的には, 韓 国人ではイヌッゲの自然樹形よりも段づくりの人為樹形で停留点 数が多く停留時間が長いのに対し, 日本人では大きな違いが見ら れなかった。また, 球形のドウダンッッジの自然樹形と人為樹形 において韓国人では大きな違いが見られなかったが，日本人では 視点の軌跡に大きな違いが見られた。そして円錐形のチャボヒバ の自然樹形と人為樹形では日韓ともに大きな違いはなかったとし ている。

このように植栽形態に異なる特徵をもつ韓国と日本において, 樹形に対する印象や眼球運動の比較研究はあるが, 複数の個体か らなる植栽を対象にした検討は為されていない。

そこで本研究では, 韓国と日本の複数個体からなる植栽形態に
おいてもっとも単純な対植を対象にして, 韓国人と日本人の好み の度合いと眼球運動を比較検討することとした。

\section{2. 研究方法}

\section{(1) アンケート}

韓国人と日本人を対象に図 1 に示す 5 つのパターンの対植に対 する好みの度合いについて写真を用いたアンケート調査を行った。 対植に用いた樹形は，エメラルドグリーン（Thuja occidentalis Linn.) の円錐形とヒノキ (Chamaecyparis obtusa Sieb. et Zucc.) の球形とした。これらは両国でよく見られる樹種・樹形 である。また，対植以外の要因の影響を排除するため，錸は茶色 のプラスチック鉢，背景は白のスクリーンとした。なお，円錐形 之球形樹形では根鉢の形状が異なることから前者は後者に比べて 縦長なものとなった。各対象木の形状は表のとおりである。

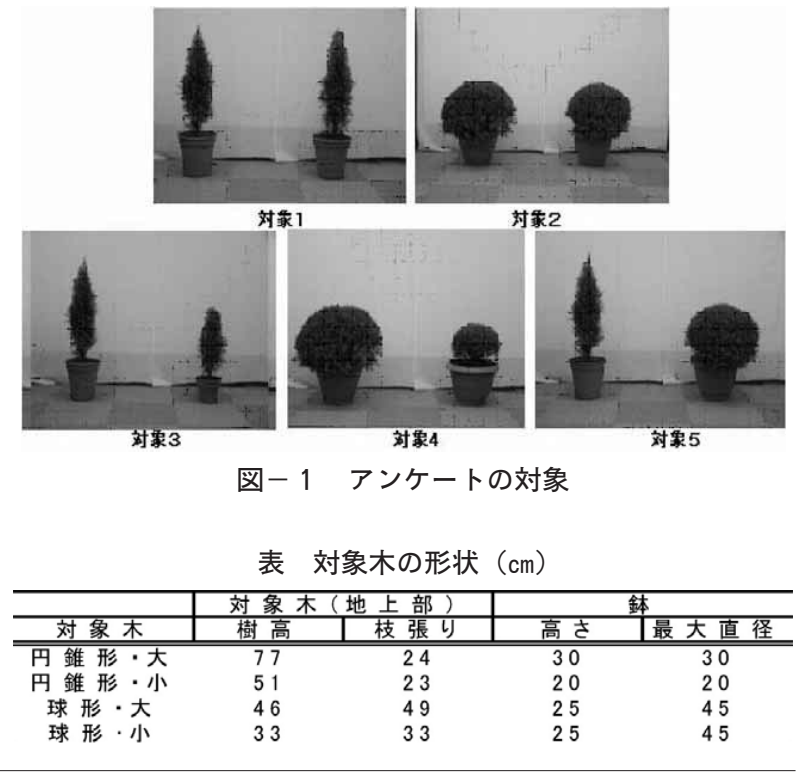

*アリアンスフレル ${ }^{* *}$ 千葉大学大学院自然科学研究科 ${ }^{* * *}$ 千葉大学園芸学部 
アンケート対象者は, 両国ともに年齢 20-50 代の社会人や学生 などで, 日本人は男性 30 人, 女性 31 人の計 61 人, 韓国人は男 性 84 人, 女性 8 人の計 92 人に対して調查を行った。アンケート は被験者に図 1 の写真を載せた用紙を渡し, 好きな順に 1 位から 5 位までランク付けしてもらった。アンケート調査は 2004 年 6 月から 10 月の間に実施した。

\section{(2) 眼球運動}

眼球運動の測定対象とした対植は, アンケート調查の対象とし た 5 つの対植パターンに, 図 2 のように左右を入れ替えたパター ンを加え, 計 8 パターンとした。
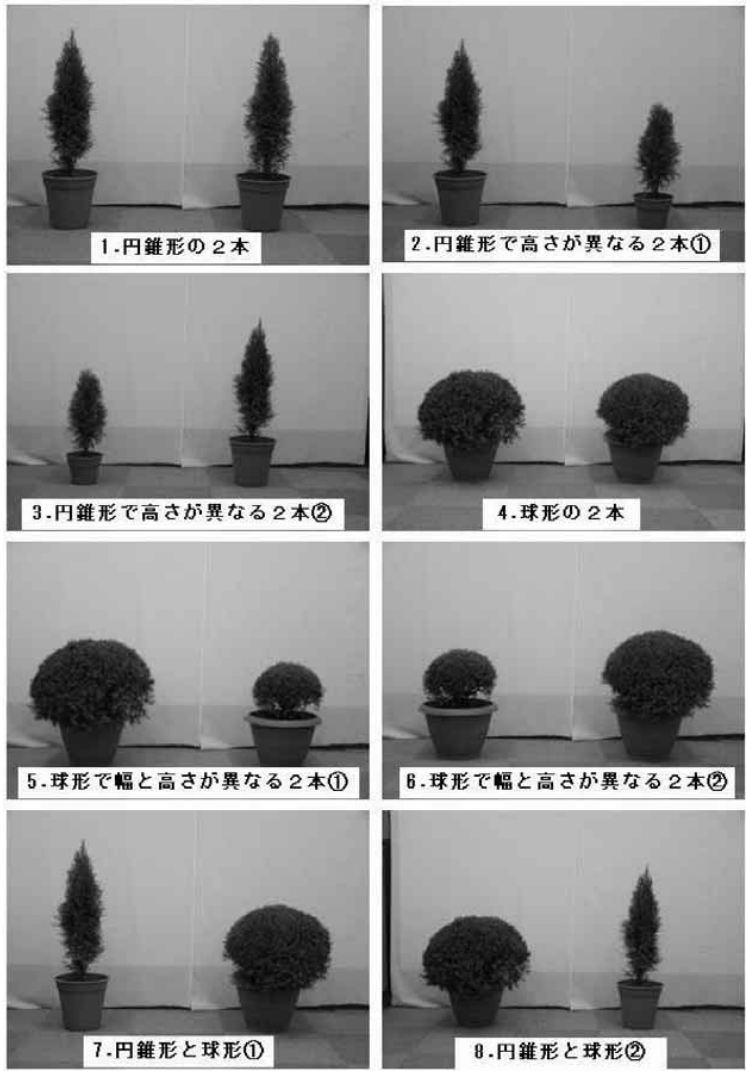

図一 2 眼球運動計測を行った視覚対象

実験場所は被験者が対象物之背景以外の要因から受ける影響を できる限り少なくし，全被験者が同一条件下で実験が受けられる ように, 千葉大学園芸学部のシールドルーム内とした。2 本の対 象木の間隔は田辺ら $(1993)^{6)}$ の実験を参考に被験者が頭部を動 かさずに両樹木を関連づけて見ることができる範囲である直径視 角 16.26 度以内（植栽間隔 $1.0 \mathrm{~m} ）$ とした。そして, 樹木からの 距離と眼球運動の関係を検討した寺井ら (1991） ${ }^{7)}$ の実験を参考 に, 対象木と被験者の距離は $3.5 \mathrm{~m}$ とした（図 3 , 図 4 )。

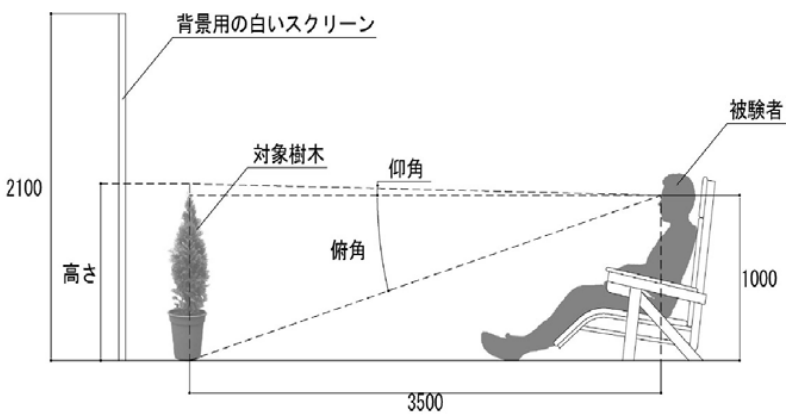

図-3 実験状況－立面図（単位mm）
実験では被験者はいすに座り，その視点の高さをほぼ $1.0 \mathrm{~m}$ と した。測定開始前に被験者には対象木を見ている間は頭を動かさ ないように指示した。そして，島(1982） ${ }^{11}$ や二瓶 (2003) ${ }^{14)}$ を参考 に，各対象ごとに 60 秒間の測定をそれぞれ行った。途中，対象 木を取り替える際には仕切りで遮蔽して対象木を配置した。また, 被験者によって対象を提示する順番はランダムにした。一人当た りの平均実験時間は約 40 分間であった。

眼球運動の測定と記録には角膜・瞳孔反射法を利用した非拘束 式型（ナックイメージテクノロジー社, 日本）アイマークレコー ダ EMR-8：MODEL ST-560) を用いた。

被験者は両国の 20 代の男性で裸眼もしくは矯正視力が 0.7 以 上の日本人 10 人 (千葉大学園芸学部の男性学生), 韓国人 9 人 (千葉大学留学生 8 人, 日本工業大学留学生 1 人) であった。本 実験は 2004 年 10 月から 11 月までの間に行った。

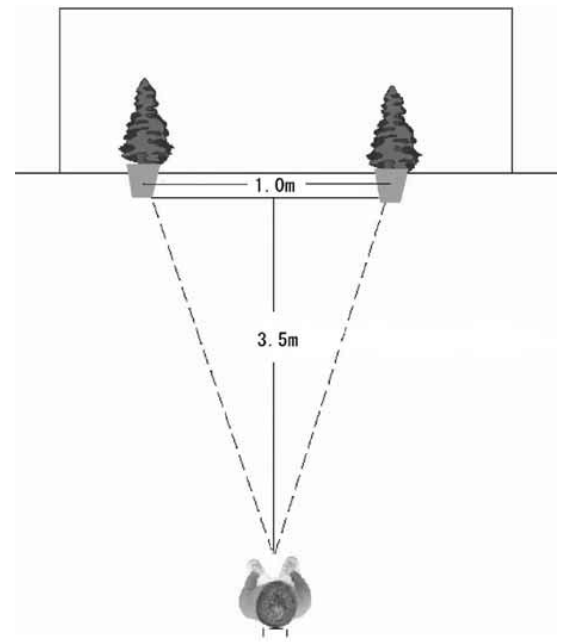

図－4 実験状況－平面図

\section{3. 結果および考察}

\section{(1) アンケート結果}

両国被験者ごとに最も高く評価された対植パターンと最も低く 評価されたパターンは, 図 5 の通りであった。両国被験者ともに 球形 2 本の対植（対象 2 ）を最も好む人が多かった。一方, 最む 低く評価されたパターンは両国ともに円錐形で高さが異なる 2 本 の対植（対象３）で，韓国被験者ではさらに円錐形之球形の対植 （対象 5 ）も低く評価された。
韓国人
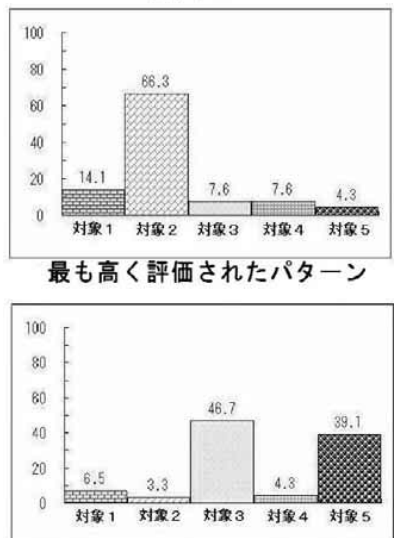

最も低く評価されたパターン
日本人

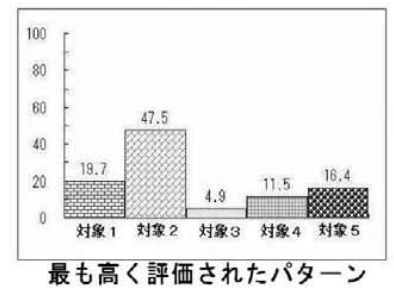

図－5 アンケート調査の結果 
これに対して, 日本人被験者では球形で高さの異なる 2 本（対 象 4 ）および対象 5 を低く評価する人がやや多いものの, 同時に 最も高く評価する人も少なからずいた。

このことから, 韓国人被験者では樹形と高さが同じ 2 本の典型 的な対植を好む傾向が明確であるのに対し, 日本人では典型的な 対植を好む人は多いながらも異なる樹形の対植を好む人屯少なか らずいることがわかる。
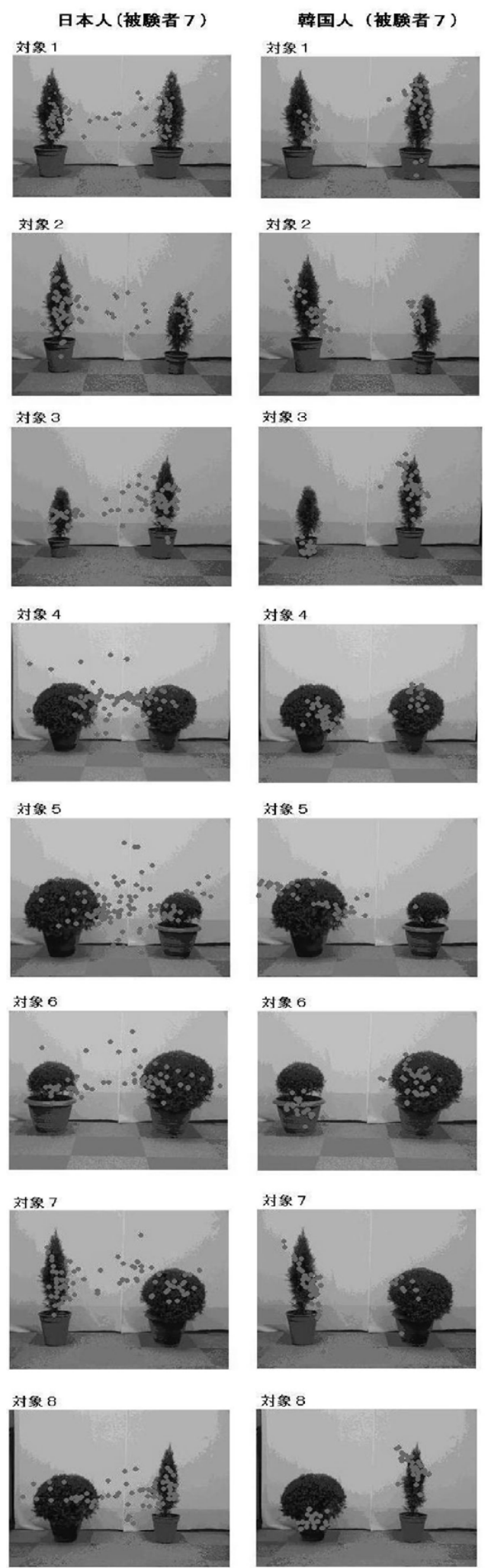

図-6 停留点分布の一例

\section{(2) 眼球運動}

(i) 停留点分布

全対象に対する停留点分布を見ると, 韓国人被験者の多くで日 本人被験者と比べて各対象木に対する停留点分布が狭い傾向が見 られた。一方, 日本人被験者では各対象木の中心部から輪郭まで 停留点が広く分布する傾向が多く見られた。この傾向は自然樹形 と人為樹形に対する眼球運動の比較実験 (金・藤井, $1993^{3}$ ) で, 停留点の分布が自然樹形では日韓ともに対象木全体に広がるが, 人為樹形では韓国人はその中央部に集中するのに対し，日本人は 幹と輪郭に停留点が偏る傾向があるとした結果と類似するものと 考えられる。

韓国人で 2 本の対象木上に停留点が集中する傾向は，同じ樹形 からなる典型的な対植で明確であり，またそれらでは好みの度合 いも高かったことを合わせて考えると, 対象木に眼球運動が集中 できる対植パターンを好む傾向があるものと考えられる。そして, 好みの度合いが低かった異なる樹形からなる対植パターンでは, 樹木上に停留点が広く分布し，また両樹木の間の空間にも分布す る傾向が見られた。

これに対して日本人の場合はすべてのパターンにおいて 2 本の 対象木上だけではなく, その間の空間にも停留点が分布する傾向 が多く見られた。また，アンケートにおいて，同じ樹形を持つ典 型的な対植を好む度合いが高い一方, 樹形の異なる対植を好む人 屯少なからずいたことから，日本人は対象木だけを認識するので はなく, 対象木とその間の空間あるいは背景とをあわせて観察す る傾向があると考えられる。

また, 日本人 3 人（被験者 $5,6,8)$ において, 円錐形樹形 で高さの異なる対植（向って左側が背の高い樹木：対象 2 ）では 停留点が対象木上に集中するが，左右を入れ換えた対象 3 におい ては, 対象木以外にも停留点が分散する傾向が見られた。これは 韓国人被験者では見られない傾向であった。

このような結果から, 韓国人被験者は背景よりも対象木を中心 に捉える傾向があるのに対して，日本人被験者は対象木をその間 の空間あるいは背景との関係で捉える傾向があると考えられる。

(ii) 視覚対象範囲を 3 区分した場合の停留時間, 停留点数

上述のように停留点分布に扔いて韓国人と日本人とで異なる傾 向が見られたことから, 図 7 のように視覚対象範囲を 3 区分した 場合の停留時間と停留点数をWilcoxon の順位和検定を用いて韓 国人と日本人の比較を行った。

区分方法については，対象をはっきりと捉えることができる中 心視 ${ }^{8)}$ の範囲が対象樹木の中心から左右 $31.0 \mathrm{~cm}$ の範囲であるこ とから,「中」は左右の樹木の中心から $31.0 \mathrm{~cm}$ 離れた地点に挟 まれた範囲とし，それより左側を「左」，右側を「右」とした。

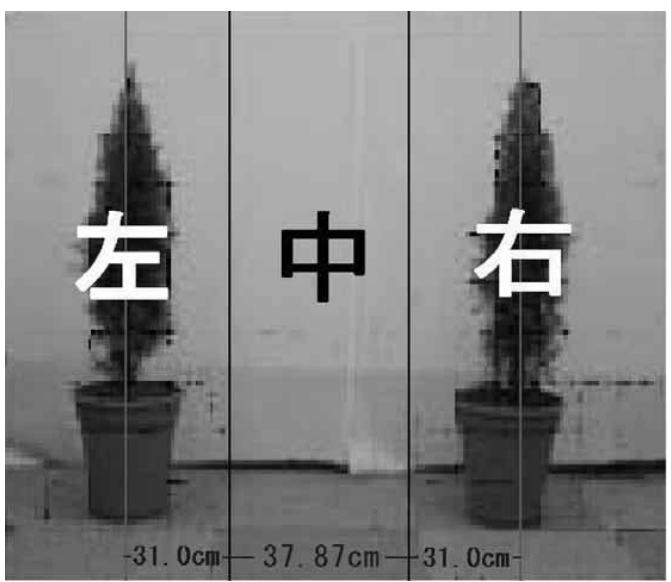

図-7 視覚対象範囲の区分方法 
その結果, 図 8 に示すように, 円錐形 2 本 (対象 1 ), 円錐形 で高さの異なる 2 本で向って左側が背の低いもの（対象 3 ), 球 形で高さの異なる 2 本で向って右側が背の低いもの（対象 5 ), 対象 5 の左右を入れ替えた 2 本 (対象 6 ) の「中」において韓国 人と日本人の間に有意差が見られた。
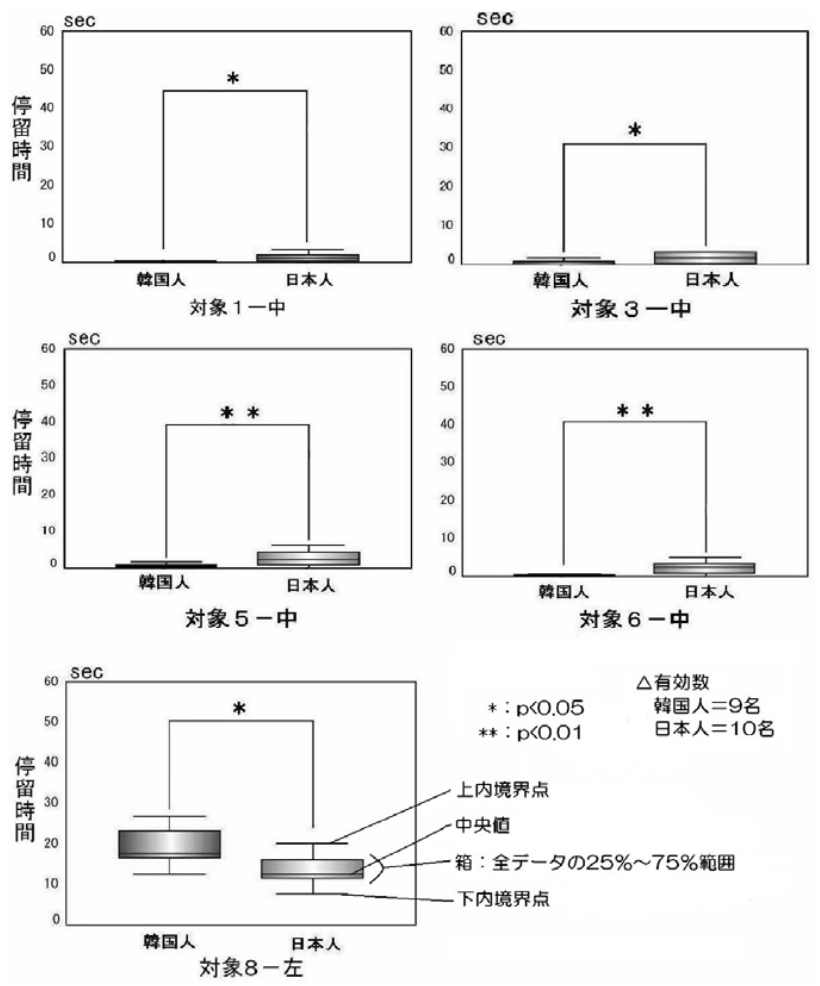

図-8 視覚対象範囲を 3 区分した場合の 韓国人と日本人の停留時間の比較

*グラフ中の上内境界点および下内境界点はデータのばらつきの大きさを示 し，その值は中央值 $\pm 1.5 \times$ (第 3 四分数 - 第 1 四分数）で求められる。

これらのことから，これら 4 つの対象において日本人は 2 本の 樹木の中間に視点をより多く停留させることがわかる。

また，対象 8 の「左」においても韓国人と日本人との間に有意 差が見られたことから, 図 9 に示すように, 韓国人被験者は 2 本 の樹木だけを平均的にとらえるのに対して, 日本人被験者は 2 本 の樹木とともにその中間にも視点を停留させる傾向があり, また 左の樹木より右の樹木の方に視点を停留させる傾向があるといえ よう。
$N=9$
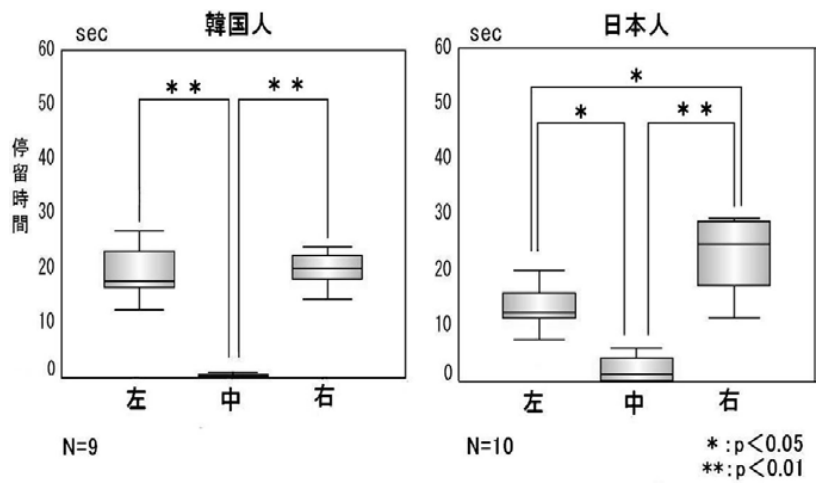

図－9 韓国人と日本人の視覚対象 8 における各範囲の停留時間

\section{4.まとめ}

停留点分布では韓国人被験者は 2 本の対象木上に停留点が集中 する傾向があるのに対して，日本人では 2 本の対象木上だけでは なくその間の空間にも停留点が分布する傾向が見られた。

また，視覚対象範囲を左，中，右の 3 つに区分した場合の停留 時間, 停留点数でもいくつかの対象において韓国人と日本人之の 間に有意差が見られた。特に視覚対象範囲の「中」で両国被験者 の間に有意差が見られたことから，日本人には 2 本の樹木の中間 に視点を停留させる傾向のあることが明らかとなった。

そして, 眼球運動とアンケート調査の結果を合わせ考えると, 韓国人被験者で 2 本の対象木上に停留点が集中する傾向があり， またこの傾向が好みの度合いの高い対植パターンで高くなる傾向 があったことから，対植の 2 本の樹冠上に停留点が集中すること と好みとの間には関連性があるものと考えられる。

これに対して，日本人被験者では 2 本の対象木上だけでなくそ の間の空間にも停留点が分布する傾向があり，また同じ樹形を持 つ典型的な対植を好む度合いが高い一方で，樹形タイプの異なる 2 本の対植を好む人屯ある程度いたことから，対象木をその間の 空間や背景との関係でとらえる傾向があると考えられる。

以上のことから，韓国人被験者は対植を対象木中心に観察する 点に特徵があり，一方日本人被験者は対象木とその間の空間ある いは背景とをあわせて観察する点に特徵があるといえよう。そし て, このような特徵は, 前述した日韓両国の一般的な植栽パター ンと, それに対する好みや眼球運動との間の関連性を窥わせるも のである。

\section{引用・参考文献}

1 ）藤井英二郎・李基徹・金承煥 - 系賀黎（1990）：韓国・清道 地域の農家の庭について：造園雑誌 53(5)，404-405

2 ) 白志星・藤井英二郎・仲隆裕 - 浅野二郎（1992）：韓国・昌 徳宮の燕朝における庭園植栽について：造園雑誌 55(5), 1-6

3 ）藤井英二郎（1995）：見る庭と触れる庭，56-69, 淡交社

$4 ）$ 金恩一・藤井英二郎（1992）：幾何学的図形に対する韓国人 と日本人の眼球運動の比較一植栽と眼球運動の関係に関する 基礎実験一：千葉大学園芸学部学術報告 46, 215-220

5 ) 金恩一・藤井英二郎（1993）：自然樹形と人工樹形に対する 眼球運動の比較一韓国人と日本人の男性を対象としてー：千 葉大学園芸学部学術報告 $47,165-170$

6 ) 田辺聡（1993）：高さの異なる 2 本の樹木間の距離と眼球運 動の関係：千葉大学園芸学部卒業論文, 1-115

7 ) 寺井泰 (1992)：樹木からの距離と眼球運動の関係について: 千葉大学園芸学部卒業論文, 1-211

8 ）三浦利章（1996）：行動之視覚的注意：風間書房，1-49

9 ）藤井英二郎・升谷素弥・仲隆裕・安蒜俊比古（1991）：樹木 からの距離と注視特性の関係－キンモクセイの自然樹形の場 合一：千葉大学園芸学部学術報告 44, 165-172

10）古賀一男（1998）：眼球運動実験ミニ・ハンドブック：労働 科学研究所出版部, 1-138

11）島隆正（1982）：注視点移動パターンによる形状認識の研究： 千葉大学大学院工学研究科修士論文, 1-144

12）南博 (1983)：間の研究：講談社, 7-20

13）大谷璋（1968）：眼球運動の時間特性：人間工学 4(1), 2936

14）二塀真英（2003）：眼球運動を指標とした樹木の「おもて」 の識別に関する認知心理学的研究：千葉大学大学院自然科学 研究科修士論文, $1-45$ 